\title{
CTX-M-9 group ESBL-producing Raoultella planticola nosocomial infection: first report from sub-Saharan Africa
}

\author{
Tafese Beyene Tufa ${ }^{1,2,3^{*}+}$ (D) Andre Fuchs ${ }^{2,3 \dagger}{ }^{1}$ Torsten Feldt ${ }^{2,3}$, Desalegn Tadesse Galata ${ }^{1}$, Colin R. Mackenzie ${ }^{4}$,
} Klaus Pfeffer ${ }^{4}$ and Dieter Häussinger ${ }^{2,3}$

\begin{abstract}
Background: Raoultella are Gram-negative rod-shaped aerobic bacteria which grow in water and soil. They mostly cause nosocomial infections associated with surgical procedures. This case study is the first report of a Raoultella infection in Africa.

\section{Case presentation}

We report a case of a surgical site infection (SSI) caused by Raoultella planticola which developed after caesarean section (CS) and surgery for secondary small bowel obstruction. The patient became febrile with neutrophilia $(19,157 / \mathrm{mL})$ 4 days after laparotomy and started to develop clinical signs of a SSI on the $8^{\text {th }}$ day after laparotomy. The patient continued to be febrile and became critically ill despite empirical treatment with ceftriaxone and vancomycin. Raoultella species with extended antimicrobial resistance (AMR) carrying the CTX-M-9 $\beta$-lactamase was isolated from the wound discharge. Considering the antimicrobial susceptibility test, ceftriaxone was replaced by ceftazidime. The patient recovered and could be discharged on day 29 after CS.

Conclusions: Raoultella planticola was isolated from an infected surgical site after repeated abdominal surgery. Due to the infection the patient's stay in the hospital was prolonged for a total of 4 weeks. It is noted that patients undergoing surgical and prolonged inpatient treatment are at risk for infections caused by Raoultella. The development of a SSI caused by Raoultella planticola with extended AMR has to be assumed to be a consequence of ineffective antibiotic utilization. The presented case advices that rare bacteria as Raoultella should be considered as potential cause of nosocomial SSI with challenging treatment due to high levels of AMR.
\end{abstract}

Keywords: Raoultella planticola, Nosocomial infection, Antimicrobial resistance, Extended spectrum $\beta$-lactamases, ESBL, CTX-M-9 group, Africa, Ethiopia

\section{Background}

Raoultella are Gram-negative rod-shaped aerobic bacteria growing in water and soil. They can also be detected in the human gastrointestinal tract (GIT) or upper

\footnotetext{
*Correspondence: tafeseb.tufa@yahoo.com

${ }^{\dagger}$ Tafese Beyene Tufa and Andre Fuchs contributed equally to this work ${ }^{1}$ Asella Teaching and Referral Hospital, College of Health Sciences, Arsi University, P.O. Box 04, Asella, Ethiopia

Full list of author information is available at the end of the article
}

respiratory tract (URT) and are a rare cause of mostly nosocomial infections in humans. They were defined as a new genus in the family of Enterobacteriaceae in 2001, based on gene sequences of its $16 \mathrm{~S}$ rRNA and rpoB gene [1]. Raoultella can grow at wide range of temperature $\left(4{ }^{\circ} \mathrm{C}\right.$ to $\left.44.5^{\circ} \mathrm{C}\right)$ and do not produce gas from lactose at $44.5^{\circ} \mathrm{C}$. All Raoultella isolates are resistant to ampicillin due to the over expression of chromosomally encoded class-A $\beta$-lactamase [2].

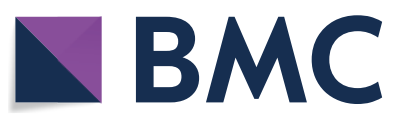

(c) The Author(s) 2020. This article is licensed under a Creative Commons Attribution 4.0 International License, which permits use, sharing, adaptation, distribution and reproduction in any medium or format, as long as you give appropriate credit to the original author(s) and the source, provide a link to the Creative Commons licence, and indicate if changes were made. The images or other third party material in this article are included in the article's Creative Commons licence, unless indicated otherwise in a credit line to the material. If material is not included in the article's Creative Commons licence and your intended use is not permitted by statutory regulation or exceeds the permitted use, you will need to obtain permission directly from the copyright holder. To view a copy of this licence, visit http://creativecommons.org/licenses/by/4.0/. The Creative Commons Public Domain Dedication waiver (http://creativecommons.org/publicdomain/zero/1.0/) applies to the data made available in this article, unless otherwise stated in a credit line to the data. 
Raoultella planticola, $R$. ornithinolytica, $R$. terrigena, and $R$. electrica are medically relevant Raoultella species [3-6], with $R$. planticola and $R$. ornithinolytica currently being most commonly reported from clinical samples. Factors contributing to the pathogenesis of diseases caused by the genus of Raoultella share similarities with those of Klebsiella and include lipopolysaccharides, polysaccharide capsules, fimbriae, siderophores [7], toxins [8], hydrolytic enzymes, and bacteriocins [9]. Raoultella species are also able to form biofilms [10]. In contrast to Klebsiella species, Raoultella species harbour histidine decarboxylase, enabling the bacteria to produce histamine. This information might be used for species differentiation [11, 12].

Following phenotypic and biochemical microbiological methods only, Raoultella species are most likely being underreported due to the difficult differentiation from Klebsiella species. Over recent years, the identification rate has improved by increased utilization of matrix-assisted laser desorption/ionization-time of flight mass spectrometry (MALDI-TOF MS) [13].

Raoultella planticola is not well known as human pathogen. Literature search revealed 87 reported cases of R. planticola-related infections. Here, bloodstream infections (32 cases), urinary tract infection (16 cases), and pneumonia (11 cases) are most frequent. Among abdominal foci of Raoultella-infections, 5 cases of cholangitis, 3 cases of pancreatitis, 3 cases of cholecystitis, 3 cases of surgical site infection (SSI), 2 cases of secondary bacterial peritonitis, and a single case of enterocolitis have been described. Antimicrobial resistance (AMR) of Raoultella causing human infections has not been analysed systematically. However, Raoultella species harbouring extended spectrum $\beta$-lactamase (ESBL) and carbapenemase genes have been reported [14-17]. Most of the cases were reported in Europe and the USA. To our best knowledge, this report is the first description of an SSI caused by $R$. planticola with multidrug resistance (MDR) in Africa.

\section{Case presentation}

\section{Initial presentation}

A 17-year-old previously healthy pregnant woman presented to Asella Teaching and Referral Hospital (ATRH) delivery ward in Asella, Central Ethiopia. Upon admission she appeared healthy, without any signs of infection or life-threatening disease. Caesarean section (CS) was indicated due to posterior cephalic position of the child and large fetal size. Lower uterine transverse CS was performed and a healthy male neonate delivered.

\section{Development of surgical site infection}

For the first three days after delivery, the patient recovered well from her surgery. However, on the $4^{\text {th }}$ day she developed cramping abdominal pain, constipation with clinical signs of ileus and an elevated body temperature (T) of $37.8^{\circ} \mathrm{C}$. After physical examination and abdominal $\mathrm{X}$-ray revealed signs of small bowel obstruction, emergency laparotomy was performed. Intra-operative findings were a purulent peritonitis due to a volvulus of the cecum with formation of a gangrene. Peritoneal drainage and lavage and a right hemicolectomy with primary ileotransverse anastomosis were performed. The postoperative course for the first days was uneventful.

On her 5th day after laparotomy (and 9th after CS) the patient developed shortness of breath with mild hypotension, tachycardia, tachypnea and fever (blood pressure (BP) $110 / 70 \mathrm{mmHg}$, pulse rate (PR) $108 / \mathrm{min}$, RR 40/min, $\mathrm{T} 38.5^{\circ} \mathrm{C}$ ). Breath sounds were clear with good bilateral air entry. Abdominal examination revealed passage of faecal matter from the surgical site. Complete blood count $(\mathrm{CBC})$ showed leucocytosis $\left(21.5 \times 10^{3} / \mu \mathrm{l}\right)$ with an increased fraction of neutrophils (89.1\%). Platelet count and haemoglobin level where within normal range. There was no growth in a blood culture for a total incubation period of 5 days ( 1 bottle, local production).

\section{Further course and treatment}

The patient was diagnosed with a suspected intestinal anastomotic leak and empiric parenteral antibiotic treatment was started according to local guidelines with $1 \mathrm{~g}$ ceftriaxone plus $1 \mathrm{~g}$ vancomycin daily. Re-laparotomy on the same day revealed intraperitoneal pus and faeces due to an anastomotic dehiscence with perforation of the distal ileum about $50 \mathrm{~cm}$ from the previous anastomosis. After dissection of the insufficient anastomosis, resection of necrotic intestine and peritoneal lavage, re-anastomosis and closure of the abdominal cavity were performed.

On the $6^{\text {th }}$ day post re-laparotomy (11 days post first laparotomy and 15 days after CS), the patient was transferred to intensive care unit and she developed purulent discharge from the surgical site. At this time, a wound swab was taken for microbiological diagnostics. The culture revealed growth of Raoultella species and the previous antibiotic treatment was adjusted according to the drug susceptibility test result (see Table 1) by replacement of ceftriaxone with ceftazidime. After 7 days of parenteral antibiotic treatment with this new regimen (ceftazidime $1 \mathrm{~g}$ three times daily and vancomycin $1 \mathrm{~g}$ once daily) the patient developed frequent watery diarrhoea and bilateral lower extremity swelling. Because of suspected Clostridium difficile 
Table 1 Results of antimicrobial susceptibility testing of Raoultella planticola isolated strain

\begin{tabular}{|c|c|c|c|c|}
\hline \multirow[t]{2}{*}{ Name of antimicrobial substance } & \multicolumn{2}{|c|}{ Kirby-Bauer disc diffusion test ${ }^{a}$} & \multicolumn{2}{|c|}{ VITEK $^{\circledR} 2$ result } \\
\hline & Diameter (mm) & EUCAST interpretation & MIC & $\begin{array}{l}\text { EUCAST } \\
\text { interpretation }\end{array}$ \\
\hline Piperacillin & 0 & $\mathrm{R}$ & $\geq 128$ & $\mathrm{R}$ \\
\hline Piperacillin/tazobactam & 21 & $S$ & 8 & S \\
\hline Cefotaxime & 0 & $\mathrm{R}$ & 8 & $\mathrm{R}$ \\
\hline Ceftazidime & 22 & $S$ & $\leq 1$ & S \\
\hline Cefepime & 22 & । & $\leq 1$ & S \\
\hline Aztreonam & Not tested & & 2 & । \\
\hline Imipenem & 26 & $S$ & 0.5 & S \\
\hline Meropenem & 27 & $\mathrm{~S}$ & $\leq 0.25$ & S \\
\hline Amikacin & 20 & S & $\leq 2$ & S \\
\hline Gentamicin & 9 & $\mathrm{R}$ & $\geq 16$ & $\mathrm{R}$ \\
\hline Tobramycin & 12 & $\mathrm{R}$ & 8 & $\mathrm{R}$ \\
\hline Moxifloxacin & Not tested & & 2 & $\mathrm{R}$ \\
\hline Tigecycline & Not tested & & 1 & S \\
\hline Ciprofloxacin & 17 & $\mathrm{R}$ & 1 & $\mathrm{R}$ \\
\hline Fosfomycin & Not tested & & $\leq 16$ & $\mathrm{~S}$ \\
\hline Colistin & Not tested & & $\leq 0.5$ & S \\
\hline Trimethoprim/sulfamethoxazole & Not tested & & $\geq 320$ & $\mathrm{R}$ \\
\hline
\end{tabular}

MIC minimum inhibitory concentration; $R$ resistant, $S$ sensitive, $/$ intermediate

a Results of antimicrobial susceptibility testing (AST) was done by using disc diffusion method at Asella, Ethiopia whereas VITEK was performed at institute of Medical Microbiology and Hospital Hygiene, Düsseldorf, Germany. Both results were interpreted by using European Committee on Antimicrobial Susceptibility Testing (EUCAST) version: 08.01

enteritis (diagnostic tests for Clostridium difficile are not available), intravenous antibiotics were discontinued and the patient was started on oral metronidazole. Along with easing of the diarrhoea, the patient recovered and could be discharged in good condition on the $29^{\text {th }}$ day after CS. In general the case was summarized by (Fig. 1).

\section{Microbiology results}

During the patient's stay in the hospital, one blood culture and one wound swab from the surgical site were sent for microbiological culture. Despite the intraoperative finding of purulent peritonitis upon first laparotomy, no intraoperative swabs were ordered. The blood culture remained sterile after an incubation period of 5 days. The swab taken from the SSI 15 days after CS and before

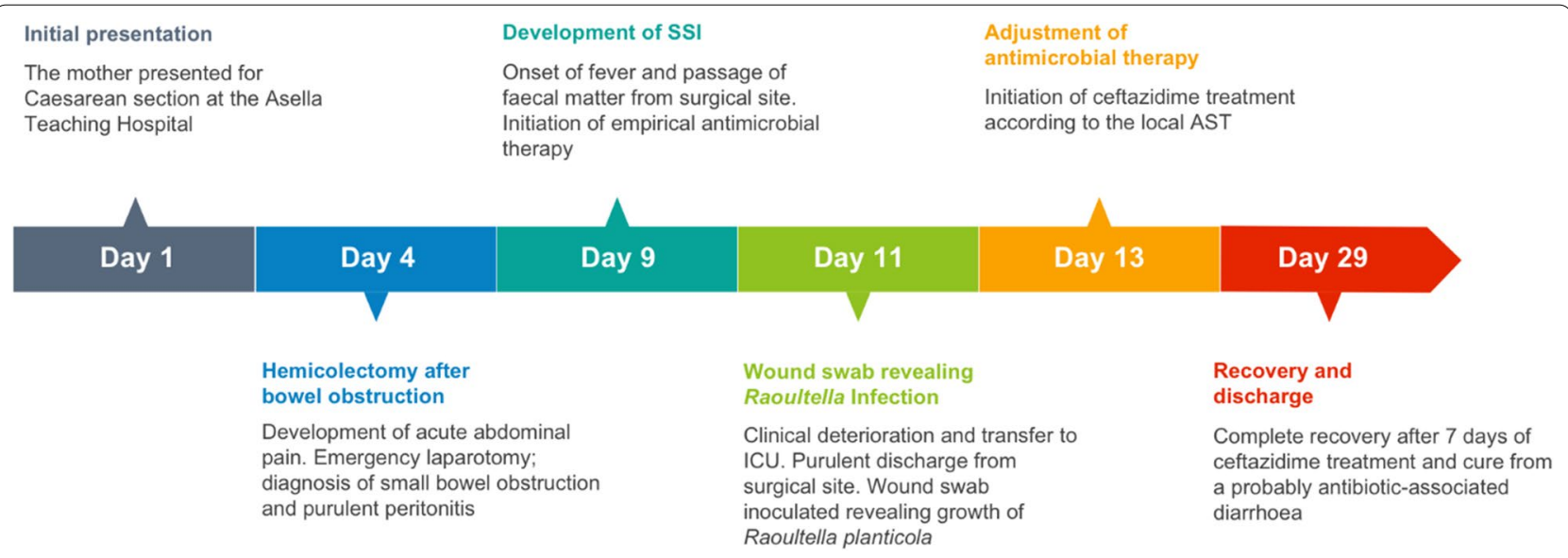

Fig. 1 Timeline of the development and course of the surgical site infection 
the $2^{\text {nd }}$ laparotomy was positive for Gram-negative rodshaped bacteria. According to biochemical identification tests performed on site in Ethiopia, the isolated bacteria were identified as Klebsiella oxytoca (oxidase and methyl red negative; lactose, urease, citrate and indole positive). The isolate was exported to the Institute of Medical Microbiology and Hospital Hygiene at Heinrich Heine University Düsseldorf, Germany for confirmation, further identification and antimicrobial susceptibility testing (AST)". Using MALDI-TOF (VITEK ${ }^{\circledR}$-MS, bioMérieux, Marcy-l'Étoile, France), the bacteria was re-classified as Raoultella planticola with a likelihood of $99.9 \%$.

The AST was done using Kirby-Bauer disc diffusion and VITEK methods. The results of the disc diffusion test and the VITEK $^{\circledR} 2$ (bioMérieux) investigation are described in (Table 1). For molecular resistance gene detection, polymerase chain reactions with primers described in (Table 2) were performed [18].

CTX-M-9 group and TEM ESBL coding genes were detected and the isolated strain was identified as MDR (Fig. 2). However, ESBLs from the groups CTX-M-1, CTX-M-2 or the SHV $\beta$-lactamase were not detected.

\section{Discussion}

Cases of infections caused by Raoultella planticola including infections with abdominal foci have been reported from different countries [19]. In addition, the isolation of Raoultella species as the causative agent of human infections containing ESBL and also carbapenemase genes have previously been reported. It is assumed that, to date, Raoultella species are often misdiagnosed as Klebsiella species in the context of restricted diagnostic capacities in many African laboratories. Therefore, and to

Table 2 Oligonucleotide sequences of the primer pairs for molecular resistant genes detection

\begin{tabular}{|c|c|c|}
\hline Primer & Sequence $\left(5^{\prime}-3^{\prime}\right)$ & $\begin{array}{l}\text { Amplicon } \\
\text { size (bp) }\end{array}$ \\
\hline $\operatorname{bla}_{S H V}(F)$ & AGCCGCTTGAGCAAATTAAAC & 786 \\
\hline bla $_{S H V}(R)$ & GTTGCCAGTGCTCGATCAGC & \\
\hline bla $_{\text {TEM }}(\mathrm{F})$ & CATTTCCGTGTCGCCCTTATTC & 846 \\
\hline bla $_{\text {TEM }}(\mathrm{R})$ & CCAATGCTTAATCAGTGAGGC & \\
\hline bla $_{\text {CTX-M-1 }}(F)$ & CGTCACGCTGTTGTTAGGAA & 781 \\
\hline bla $_{\text {CTX-M-1 }}(\mathrm{R})$ & ACGGCTTTCTGCCTTAGGTT & \\
\hline bla $_{C T X-M-2}(F)$ & CTCAGAGCATTCGCCGCTCA & 843 \\
\hline $\operatorname{bla}_{\text {CTX-M-2 }}(\mathrm{R})$ & CCGCCGCAGCCAGAATATCC & \\
\hline $\operatorname{bla}_{C T X-M-9}(F)$ & GCGCATGGTGACAAAGAGAGTGCAA & 876 \\
\hline $\operatorname{bla}_{C T X-M-9}(R)$ & GTTACAGCCCTTCGGCGATGATTC & \\
\hline
\end{tabular}

Possible extended spectrum $\beta$-lactamases (ESBLs) coding genes were screened by using conventional polymerase chain reaction (PCR)

$F$ forward, $R$ reverse, $b p$ base pairs

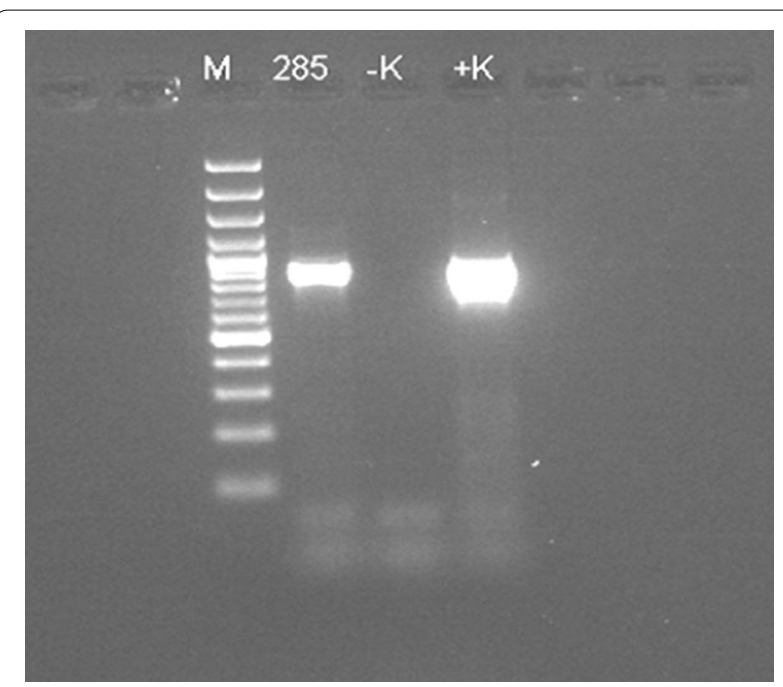

Fig. 2 Picture of blaCTX-M-9 ESBL positive result. blaCTX-M-9 ESBL gene detected in the isolated $R$. planticola strain (with $M=D N A$ ladder; $-\mathrm{K}=$ negative control; $+\mathrm{K}=$ positive control; $285=$ code given for patient's sample

our best knowledge, the described hospital-acquired SSI caused by an ESBL-producing strain of $R$. planticola is the first such case reported in Africa. The bacterial strain was isolated from a SSI after CS complicated by cecal volvulus with secondary peritonitis due to a breakdown of the primary anastomosis. Due to secondary infection the patient's overall stay in the hospital was prolonged. It is noted that being immunocompromised, surgical procedures, long-term antibiotic therapy and prolonged stays in hospital have been described as risk factors to develop Raoultella infections [17, 20]. In our case report, the patient's gastrointestinal tract has probably been colonized with $R$. planticola and the leakage of intestinal luminal contents and gut flora after anastomosis insufficiency was the likely route of the infection. It appears likely that, selection of resistant bacteria by the previous empirical antibiotic therapy with ceftriaxone, which was ineffective against identified $R$. planticola.

Cases of Raoultella infections can occur in many organ systems (e.g. urinary tract, gastrointestinal tract, respiratory tract) or at surgical sites. Bacteraemia, osteomyelitis, meningitis, cerebral abscess, mediastinitis, pericarditis, conjunctivitis, mandibular osteomyelitis and otitis caused by Raoultella have also been reported [20, 21]. In general, the most common microorganisms isolated from SSIs after small bowel surgery are aerobic Gram-negative enteric bacteria [14].

Regarding the management of intra-abdominal infections, therapy should focus on adequate source control and appropriate adjustment of antimicrobial therapy to individual patient factors. Empiric antimicrobial therapy 
is essential [22], however inappropriate antibiotic therapy may result in unfavourable outcome and in the selection of bacterial AMR bacteria. As seen in the described case, health care-associated infections caused by multiresistant bacteria have to be considered which lead to the necessity of complex multidrug regimens [23]. For the selection of empirical antibiotic treatment, a length of hospital stay of 5 days has moderate specificity and very high sensitivity for predicting the presence of MDR bacteria [24].

Due to the high likelihood of infections caused by resistant bacteria, guidelines for empirical treatment of SSIs recommend utilization of broad spectrum antimicrobials (e.g. carbapenems) [25] which are frequently not available in resource-limited settings like Ethiopia. In the absence of carbapenems, piperacillin/tazobactam could be an option for the empiric treatment of high-risk intraabdominal infections [26, 27], which lead to high rates of mortality [28].

The initial empirical treatment in the described case was a combination of vancomycin and ceftriaxone. It was shown to be ineffective according to the subsequently available AST results (see Table 1). The patient only recovered after the antibiotic treatment was adapted according to the AST, despite the local miss-identification of the causing pathogen as Klebsiella species. If AST results are not or not yet available, the initiation of antimicrobial treatment with substances active against most Enterobacteriaceae should be considered for criticallyill patients with secondary intra-abdominal infections [29]. In general, regional and local susceptibility profiles of common bacterial isolates should be available and considered before initiation of empiric antibiotic treatments. This becomes increasingly important because of rising resistance of Gram-negative bacteria circulating in the communities. Local guidelines considering common regional AMR patterns should be implemented and updated for the management of SSI and intra-abdominal infections.

From both clinical and natural environment, MDR strains of $R$. planticola and $R$. ornithinolytica were reported [30, 31]. In recent years, infections with Raoultella strains producing ESBL from the families TEM, SHV, and CTX-M have been described [32]. The ability to produce ESBL was also detected in Raoultella strains isolated from the hospital environment. From different clinical samples, AmpC $\beta$-lactamase-producing $R$. ornithinolytica strains have been isolated [33]. Emerging organisms like Raoultella species are likely to escape routine identification or be disregarded as insignificant contaminants despite their potential to cause infections which are complicated to manage due to MDR [34]. Limitations in diagnostic microbiological capacities might lead to delayed identification of emerging pathogens and extended AMR patterns, resulting in suboptimal patient care. In the light of increasing AMR among pathogens worldwide but also in resource-limited settings, strengthening of microbiological facilities and thus improved infection surveillance and control will lead to better hospital hygiene and infection control practices, which are needed for optimal outcome and containment of spreading resistance genes.

\section{Conclusions}

This report shows evidence of an infection due to a MDR strain of $R$. planticola causing a SSI and intra-abdominal infection with the presence of the CTX-M-9 group ESBLs and is the first description of such an infection in Africa. Surgical treatment with intestinal leakage was the likely route of the infection caused by $R$. planticola. The source of the bacteria might be from gastrointestinal colonization as consequence of ineffective antibiotics utilization or from the hospital environmental. The absence of diagnostic facilities, limited awareness of treating physicians for the importance of microbiological culturing and AST, restricted availability of antibiotic substances for treatment of infections caused by MDR bacteria and lack of data for common local AMR patterns in resource limited settings is jeopardizing the success rate of empirical antibiotic treatment. These insufficiencies become more severe in patients with hospital-acquired infections and prolonged stay in a hospital. In general, the presented case serves to increase the awareness that rare bacterial species like Raoultella should be considered as a potential cause of nosocomial SSI with a high rate of AMR. This leads to the necessity of up-to-date guidelines for the management of intra-abdominal infections and for regular microbiological investigation of suitable clinical specimen in nosocomial infections.

In settings where colonization with MDR Enterobacteriaceae is common, surveillance and screening for colonization with MDR bacterial strains before invasive procedures and implementation or strengthening of antibiotic stewardship programs would contribute to successful patient care and should be considered.

\section{Abbreviations \\ AMR: Antimicrobial resistance; AST: Antimicrobial susceptibility testing; ATRH: Asella Teaching and Referral Hospital; BP: Blood pressure; CS: Caesarean sec- tion; ESBL: Extended spectrum $\beta$-lactamase; MDR: Multi-drug resistant; PR: Pulse rate; RR: Respiratory rate; SSI: Surgical site infection; T: Body temperature.}

\section{Acknowledgments}

The authors thank the study and laboratory team from Hirsch Institute of Tropical Medicine in Asella, Ethiopia and the staff of the Institute of Medical Microbiology and Hospital Hygiene, Heinrich Heine University, Düsseldorf, Germany for supporting this work. We also acknowledge the German ESTHER 
University and Hospital Partnership Program for endorsing microbiology facilities at the study site.

\section{Authors' contributions}

TBT: Design, Acquisition and interpretation of data, drafting of the manuscript. AF: Conception and design, acquisition and interpretation of data, drafting and revision of the manuscript. TF: Accountability for the published work, conception and design, interpretation of data, critical revision of the manuscript. DTG: Analysis and interpretation of data, drafting of the manuscript. Colin Mackenzie: Interpretation of data, accountability for microbiological results, critical revision of the manuscript. KP: Accountability for microbiological results, critical revision of the manuscript. DH: Critical revision of manuscript and approval of final version to be published. All authors read and approved the final manuscript.

\section{Funding}

Funding for the described microbiological investigations performed in Ethiopia were financed by the University and Hospital Partnership Programme (ESTHER Alliance for Global Health Partnerships, Germany, Federal Ministry for Economic Cooperation and Development). There was no influence of the funding organisation on analysis or interpretation of the described data.

\section{Availability of data and materials}

All data generated or analysed during this study are included in this published article [and its additional information files].

\section{Ethics approval and consent to participate}

Not applicable.

\section{Consent for publication}

The patient consented to participation and publication. The consent form (written in the patient's mother tongue, Amharic) is available upon request.

\section{Competing interests}

The authors declare that they have no competing interests.

\section{Author details}

${ }^{1}$ Asella Teaching and Referral Hospital, College of Health Sciences, Arsi University, P.O. Box 04, Asella, Ethiopia. ${ }^{2}$ Hirsch Institute of Tropical Medicine, P.O. Box 04, Asella, Ethiopia. ${ }^{3}$ Department of Gastroenterology, Hepatology and Infectious Diseases, Düsseldorf University Hospital Center, Moorenstr. 5, 40225 Düsseldorf, Germany. ${ }^{4}$ Institute of Medical Microbiology and Hospital Hygiene, Düsseldorf University Hospital Centre, Universitätsstr. 1, 40225 Düsseldorf, Germany.

Received: 19 September 2019 Accepted: 11 August 2020

Published online: 17 August 2020

\section{References}

1. Drancourt M, Bollet C, Carta A, Rousselier P. Phylogenetic analyses of Klebsiella species delineate Klebsiella and Raoultella gen. nov., with description of Raoultella ornithinolytica comb. nov., Raoultella terrigena comb. nov. and Raoultella planticola comb. nov. Int J Syst Evol Microbiol. 2001;51:925-32.

2. Walckenaer E, Poirel L, Leflon-Guibout V, Nordmann P, Nicolas-Chanoine $\mathrm{MH}$. Genetic and biochemical characterization of the chromosomal class A beta-lactamases of Raoultella (formerly Klebsiella) planticola and Raoultella ornithinolytica. Antimicrob Agents Chemother. 2004;48:305-12.

3. Bagley ST, Seidler RJ, Brenner DJ. Klebsiella planticola sp. nov: A new species of enterobacteriaceae found primarily in nonclinical environments. Curr Microbiol. 1981;6:105-9.

4. Sakazaki R, Tamura K, Kosako Y, Yoshizaki E. Klebsiella ornithinolytica sp. nov., formerly known as ornithine-positive Klebsiella oxytoca. Curr Microbiol. 1989;18:201-6.

5. Izard D, Ferragut C, Gavini F, Kersters K, de Ley J, Leclerc H. Klebsiella terrigena, a new species from soil and water. Int J Syst Evol Microbiol. 1981;31:116-27.
6. Kimura Z, Chung KM, Itoh H, Hiraishi A, Okabe S. Raoultella electrica sp. nov., isolated from anodic biofilms of a glucose-fed microbial fuel cell. Int J Syst Evol Microbiol. 2014;64:1384-8.

7. Al-Hulu SM, Al-Charrakh AH, Al-Saadi MA. Isolation and characterization of Raoultella ornithinolytica from clinical specimens in Hilla city, Iraq. Med J Babylon. 2009;7:42-7.

8. Yu VC, Yu PH, Ho KC, Lee FW. Isolation and identification of a new tetrodotoxin-producing bacterial species, Raoultella terrigena, from Hong Kong marine puffer fish Takifugu niphobles. Mar Drugs. 2011;9:2384-96.

9. Podschun R, Fischer A, Ullman U. Expression of putative virulence factors by clinical isolates of Klebsiella planticola. J Med Microbiol. 2000;49:115-9.

10. Narisawa N, Haruta S, Arai H, Ishii M, Igarashi Y. Coexistence of antibioticproducing and antibiotic-sensitive bacteria in biofilms is mediated by resistant bacteria. Appl Environ Microbiol. 2008;74:3887-944.

11. Wauters G, Avesani V, Charlier J, Janssens M, Delmee M. Histidine decarboxylase in Enterobacteriaceae revisited. J Clin Microbiol. 2004;42:5923-4.

12. Kanki M, Yoda T, Tsukamoto T, Shibata T. Klebsiella pneumoniae produces no histamine: Raoultella planticola and Raoultella ornithinolytica strains are histamine producers. Appl Environ Microbiol. 2002;68:3462-6.

13. de Jong E, de Jong AS, Smidts-van den Berg N, Rentenaar RJ. Differentiation of Raoultella ornithinolytica/planticola and Klebsiella oxytoca clinical isolates by matrix-assisted laser desorption/ionization-time of flight mass spectrometry. Diagn Microbiol Infect Dis. 2013;75:431-3.

14. Skelton WPT, Taylor Z, Hsu J. A rare case of Raoultella planticola urinary tract infection in an immunocompromised patient with multiple myeloma. IDCases. 2017:8:9-11.

15. Mehmood H, Pervin N, Israr UI Haq M, Kamal KR, Marwat A, Khan M. A rare case of Raoultella planticola urinary tract infection in a patient with immunoglobulin A nephropathy. J Investig Med High Impact Case Rep. 2018;6:2324709618780422.

16. Castanheira M, Deshpande LM, DiPersio JR, Kang J, Weinstein MP, Jones RN. First descriptions of blaKPC in Raoultella spp. (R. planticola and R. ornithinolytica): report from the SENTRY antimicrobial surveillance program. J Clin Microbiol. 2009;47:4129-30.

17. Branco JC, Oliveira AM. HortaD, Reis J (2019) Spontaneous bacterial peritonitis caused by Raoultella planticola - a rare case with literature review. Acta Gastroenterol Latinoam. 2019;49(2):150-2.

18. Strauss LM, Dahms C, Becker K, Kramer A, Kaase M, Mellmann A. Development and evaluation of a novel universal beta-lactamase gene subtyping assay for blaSHV, blaTEM and blaCTX-M using clinical and livestock-associated Escherichia coli. J Antimicrob Chemother. 2015;70:710-5.

19. Ershadi A, Weiss E, Verduzco E, Chia D, Sadigh M. Emerging pathogen: a case and review of Raoultella planticola. Infection. 2014;42:1043-6.

20. Seng P, Boushab BM, Romain F, Gouriet F, Bruder N, Martin C, Paganelli F, Bernit E, Le Treut YP, Thomas P, Papazian L, Raoult D, Stein A. Emerging role of Raoultella ornithinolytica in human infections: a series of cases and review of the literature. Int J Infect Dis. 2016;45:65-71.

21. Lam PW, Tadros M, Fong IW. Mandibular osteomyelitis due to Raoultella species. JMM Case Rep. 2018;5:e005140.

22. Sartelli M, Chichom-Mefire A, Labricciosa FM, Hardcastle T, Abu-Zidan FM, Adesunkanmi AK, Ansaloni L, Bala M, Balogh ZJ, Beltran MA, Ben-Ishay O, Biffl WL, Birindelli A, Cainzos MA, Catalini G, Ceresoli M, Che Jusoh A, Chiara O, Coccolini F, Coimbra R, Cortese F, Demetrashvili Z, Di Saverio S, Diaz JJ, Egiev VN, Ferrada P, Fraga GP, Ghnnam WM, Lee JG, Gomes CA, Hecker A, Herzog T, Kim JI, Inaba K, Isik A, Karamarkovic A, Kashuk J, Khokha V, Kirkpatrick AW, Kluger Y, Koike K, Kong VY, Leppaniemi A, Machain GM, Maier RV, Marwah S, McFarlane ME, Montori G, Moore EE, Negoi I, et al. The management of intra-abdominal infections from a global perspective: 2017 WSES guidelines for management of intra-abdominal infections. World J Emerg Surg. 2017;12:29.

23. Sartelli M. A focus on intra-abdominal infections. World J Emerg Surg. 2010;5:9.

24. Seguin P, Laviolle B, Chanavaz C, Donnio PY, Gautier-Lerestif AL, Campion $J P$, Malledant Y. Factors associated with multidrug-resistant bacteria in secondary peritonitis: impact on antibiotic therapy. Clin Microbiol Infect. 2006;12:980-5.

25. Solomkin JS, Mazuski JE, Bradley JS, Rodvold KA, Goldstein EJ, Baron EJ, O'Neill PJ, Chow AW, Dellinger EP, Eachempati SR, Gorbach S, Hilfiker M, May AK, Nathens AB, Sawyer RG, Bartlett JG. Diagnosis and management of complicated intra-abdominal infection in adults and children: 
guidelines by the Surgical Infection Society and the Infectious Diseases Society of America. Clin Infect Dis. 2010;50:133-64.

26. Gin A, Dilay L, Karlowsky JA, Walkty A, Rubinstein E, Zhanel GG. Piperacillin-tazobactam: a beta-lactam/beta-lactamase inhibitor combination. Expert Rev Anti Infect Ther. 2007;5:365-83.

27. Harris PNA, Tambyah PA, Paterson DL. $\beta$-lactam and $\beta$-lactamase inhibitor combinations in the treatment of extended-spectrum $\beta$-lactamase producing Enterobacteriaceae: time for a reappraisal in the era of few antibiotic options? Lancet Infect Dis. 2015:15:475-85.

28. Mulier S, Penninckx F, Verwaest C, Filez L, Aerts R, Fieuws S, Lauwers P. Factors affecting mortality in generalized postoperative peritonitis: multivariate analysis in 96 patients. World J Surg. 2003;27:379-84.

29. Mazuski JE, Tessier JM, May AK, Sawyer RG, Nadler EP, Rosengart MR, Chang PK, O'Neill PJ, Mollen KP, Huston JM, Diaz JJ Jr, Prince JM. The surgical infection society revised guidelines on the management of intraabdominal infection. Surg Infect (Larchmt). 2017;18:1-76.

30. Li J, Lan R, Xiong Y, Ye C, Yuan M, Liu X, Chen X, Yu D, Liu B, Lin W, Bai X, Wang Y, Sun Q, Wang Y, Zhao H, Meng Q, Chen Q, Zhao A, Xu J. Sequential isolation in a patient of Raoultella planticola and Escherichia coli bearing a novel ISCR1 element carrying blaNDM-1. PLoS ONE. 2014;9:e89893.
31. Koc S, Kabatas B, Icgen B. Multidrug and heavy metal-resistant Raoultella planticola isolated from surface water. Bull Environ Contam Toxicol. 2013;91:177-83.

32. Zurfluh K, Hachler H, Nuesch-Inderbinen M, Stephan R. Characteristics of extended-spectrum beta-lactamase- and carbapenemase-producing Enterobacteriaceae isolates from rivers and lakes in Switzerland. Appl Environ Microbiol. 2013;79:3021-6.

33. Sękowska A. Raoultella spp.-Clinical significance, infections and susceptibility to antibiotics. Folia Microbiol. 2017;62:221-7.

34. Khan ID, Sahni AK, Bharadwaj R, Lall M, Jindal A, Sashindran V. Emerging organisms in a tertiary healthcare set up. Med J Armed Forces India. 2014;70:120-8

\section{Publisher's Note}

Springer Nature remains neutral with regard to jurisdictional claims in published maps and institutional affiliations.
Ready to submit your research? Choose BMC and benefit from:

- fast, convenient online submission

- thorough peer review by experienced researchers in your field

- rapid publication on acceptance

- support for research data, including large and complex data types

- gold Open Access which fosters wider collaboration and increased citations

- maximum visibility for your research: over 100M website views per year

At BMC, research is always in progress.

Learn more biomedcentral.com/submissions 